\title{
Long-distance movement by a great fruit-eating bat, Artibeus lituratus (Olfers, 1818), in southeastern Brazil (Chiroptera, Phyllostomidae): evidence for migration in Neotropical bats?
}

\author{
Ives Simões Arnone ${ }^{1,3}$, Eleonora Trajano ${ }^{1}$, Atenisi Pulchério-Leite ${ }^{2}$ \& Fernando de Camargo Passos ${ }^{2}$ \\ ${ }^{1}$ Universidade de São Paulo, Instituto de Biociências, São Paulo, SP, Brazil. \\ ${ }^{2}$ Universidade Federal do Paraná, Departamento de Zoologia, Curitiba, PR, Brazil. \\ ${ }^{3}$ Corresponding author: Ives Simões Arnone, e-mail: bioives@gmail.com
}

ARNONE, I.S., TRAJANO, E., PULCHÉRIO-LEITE, A., PASSOS, F.C. Long-distance movement by a great fruit-eating bat, Artibeus lituratus (Olfers, 1818), in southeastern Brazil (Chiroptera, Phyllostomidae): evidence for migration in Neotropical bats? Biota Neotropica. 16(1): e0026. http://dx.doi. org/10.1590/1676-0611-BN-2015-0026

\begin{abstract}
In Brazil, bat migrations have been inferred based on seasonal variations in bat abundances observed for several species, probably as a result of variations in temperature and food availability. However, direct evidence of individual medium to long distance $(>10 \mathrm{~km})$ movements, based on marked specimens, is restricted to large frugivorous bats, genus Artibeus (Phyllostomidae). We report the longest bat movement recorded in Brazil, along $113 \mathrm{~km}$ in a straight line, difference in altitude of $738 \mathrm{~m}$, from a mixed Araucaria forest in Curitiba, PR, to the Atlantic Forest, Alto Ribeira, SP, by a female Artibeus lituratus (Olfers, 1818), over a period of 14 months. This data is consistent with the occurrence of migratory movements in Neotropical bats, such as the ecologically flexible Artibeus spp., over relatively large areas, probably with short stopover foraging intervals. Implications for the conservation of these bats are clear, as their home ranges may be much larger than their foraging areas, encompassing more than one biome and overcoming political borders.
\end{abstract}

Keywords: mark-recapture, use of space, Atlantic forest.

ARNONE, I.S., TRAJANO, E., PULCHÉRIO-LEITE, A., PASSOS, F.C. Deslocamento de longa distância por um grande morcego frugívoro, Artibeus lituratus (Olfers, 1818), no sudeste do Brasil (Chiroptera, Phyllostomidae): evidência de migração de morcegos Neotropicais? Biota Neotropica. 16(1): e0026. http://dx.doi.org/10.1590/1676-0611-BN-2015-0026

Resumo: Migrações em morcegos brasileiros têm sido inferidas a partir de variações sazonais nas abundâncias regionais das populações, provavelmente condicionadas por flutuações na temperatura e na disponibilidade de alimento. No entanto, registros de deslocamentos individuais de média a longa distância, ultrapassando suas áreas domiciliares $(>10 \mathrm{~km})$, comprovados através de marcação e recaptura, são restritos aos grandes morcegos frugívoros do gênero Artibeus (Phyllostomidae). Registramos, aqui, o maior deslocamento já publicado, de ca. $113 \mathrm{~km}$ em linha reta, entre localidades com diferença de altitude de $738 \mathrm{~m}$, respectivamente em floresta mista de araucárias, região de Curitiba, PR, e em Mata Atlântica, Alto Ribeira, SP, realizado por uma fêmea de Artibeus lituratus (Olfers, 1818), em um intervalo máximo de 14 meses. Este dado é consistente com a ocorrência de movimentos migratórios em Artibeus spp. ao longo de áreas bastante extensas, provavelmente através de várias etapas de forrageio. As implicações para a conservação desses quirópteros são claras, uma vez que os animais desta espécie podem ter áreas de vida bem maiores que suas áreas domiciliares (de forrageio), abrangendo mais de um bioma e ultrapassando limites geopolíticos.

Palavras-chave: Marcação-recaptura, uso do espaço, Mata Atlântica.

\section{Introduction}

The key role of bats in tropical ecosystems is widely recognized (Kalko 1998, Muscarella \& Fleming 2007), and several studies on the ecology of Neotropical bats, including patterns of space and habitat use, have been published in the last two decades (e.g., Charles-Dominique 1991, Fenton et al. 1992, Gannon \& Willig 1997, Kalko et al. 1996, Avila-Cabadilla et al. 2009, Trevelin et al.
2013). Yet little is known about far range dispersal and migrations of these species.

Migration is the movement of animals that follow seasonal availability of resources, whose strategies involve a great variety of schemes; this differs from dispersal, which is generally unidirectional (Krauel \& McCracken 2013). It is defined as a seasonal and cyclic population movement, but may not occur in all populations of a species (Alerstam \& Hedenström 1998, McCracken et al. 1994). 
For Dingle (1996), migrating animals have several characteristics, such as: travelling in a relatively straight line during foraging, displaying special pre-departure or post-arrival behaviors, and storing energy for use during or after the journey. Some authors do not consider shorter spatial movements in bats as migration because they do not require physiological adaptations (Fleming \& Eby 2003, McCracken et al. 1994).

In tropical and subtropical areas, long-distance migrants follow transient fruit or nectar resources (Fleming \& Eby 2003). Insect-eating bats can migrate in response to seasonally available prey, but these patterns are obscured by the lack of information on seasonal insect availability beyond agricultural pests (Krauel \& McCracken 2013). Although regional migrants are assumed to move in search of roost sites (Griffin 1945, 1970, Tuttle 1976), many latitudinal migrants are assumed to be in the pursuit of food, with roosts being a secondary factor (Krauel \& McCracken 2013).

In a recent review, Krauel \& McCracken (2013) list 88 species (10 families) that are known to migrate or are suspected of being migrants. The great majority are small and medium-sized North American and European vespertilionids, followed by molossids (weight range 10-30 g, forearm range 40-57 mm), characterized by narrow wings with high aspect ratio (Norberg $\&$ Rayner 1987) along maximum one-way recorded distances of 140 to $1,905 \mathrm{~km}$. Records of distances travelled by phyllostomids are far less common in the literature; e.g., over $1,000 \mathrm{~km}$ for the highly specialized glossophagine Leptonycteris curasoae Miller 1900 and L. nivalis (Saussure 1860), and a reference to movements less than $200 \mathrm{~km}$ long for Carollia perspicillata (Krauel \& McCracken op. cit.).

In Brazil, indirect evidence of bat migrations has been gathered by authors working on bat communities who consistently observe seasonal variations in the abundance of several species (Trajano 1996, 2003). Seasonal differences in bat abundance have also been found in other Neotropical countries, such as Costa Rica, Nicaragua and Ecuador, as analyzed by McGuire \& Boyle (2013) in the context of evidence for altitudinal migrations.

However, data on bat movements based on individual monitoring are sparse, restricted to few species and relatively short distances, on a scale of $10^{2} \mathrm{~km}$ (e.g., Trajano 1996, Esbérard 2003, Bianconi et al. 2006, Costa et al. 2006, Menezes-Jr. et al. 2008, Mendes et al. 2009, using markrecapture; Bernard \& Fenton, 2003, Mello et al. 2008, Trevelin et al. 2013, using radiotelemetry). This does not allow for the detection of patterns. Moreover, in spite of a growing interest on this subject, the lack of a common database hampers the development of integrated mark-recapture programs that would involve several research teams in different regions of Brazil (Trajano 2003).

In this paper, we report long distance movement of a large Artibeus lituratus, as evidence of far range migration or dispersion in these Neotropical frugivorous bats. This was the result of inter-team cooperation, made possible due to personal contacts.

\section{Methods}

\section{Study sites}

The bat was first captured in 2005 during a field study on urban bats at Schaffer Campus (Leite 2008), Universidade
Tuiuti do Paraná, in a neighborhood known as Pilarzinho $\left(25^{\circ} 24^{\prime} 2^{\prime \prime} \mathrm{S} 49^{\circ} 17^{\prime} 27^{\prime \prime} \mathrm{W}, 934 \mathrm{~m}\right.$ a.s.1.), north-central Curitiba, state of Paraná. The locality is a 2-hectare fragment with heavily disturbed mixed rainforest surrounded by neighborhoods composed of buildings, paved paths and a man-made lake. In the region, there are several other forest remnants; such as Bosque do Alemão (4 hectares), Bosque Zaninelle (3.7 hectares), Bosque da Vista Alegre (5.5 ha) and Parque Tingui (38 ha). According to the classification by Köppen, the climate is $\mathrm{Cfb}$, i.e., mesothermal humid, without a dry season, mild summers, and average air temperature in the warmest month below $22{ }^{\circ} \mathrm{C}$.

This individual was recaptured at the entrance of Alambari de Baixo cave $\left(24^{\circ} 33^{\prime} 24^{\prime \prime} \mathrm{S} 48^{\circ} 39^{\prime} 52^{\prime \prime} \mathrm{W}, 196 \mathrm{~m}\right.$ a.s.1.) in 2006 , during a study on bat communities from caves and surface habitats in the Alto Ribeira karst area, southeast of São Paulo state (Arnone 2008). The cave is located at Bairro da Serra, a rural district of Iporanga Co. Most of the region rests within a conservation unit - the Parque Estadual Turístico do Alto Ribeira (PETAR) - situated between the towns of Apiaí and Iporanga, with 33,000 hectares mostly covered by dense rainforest. More than 400 caves are known in the area. The region is inserted in the largest continuum of Brazilian Atlantic rainforest, encompassing other state conservation units that total approximately 275,000 hectares: Mosaico de Unidades de Conservação do Jacupiranga, Parque Estadual Carlos Botelho, Parque Estadual de Intervales, and Reserva Ecológica do Xitué. The climate of the region is classified as Cfa, i.e., humid mesothermal, without a defined dry season and having warm summers, the average air temperature in the warmest month being above $22{ }^{\circ} \mathrm{C}$.

\section{Capture and marking}

In both studies, bats were captured in mist-nets, and those that were not euthanized for identification were marked for individual recognition with metal bands on the forearm. These bands were attached to the forearm using long-nosed pliers. The bands used in both studies had individual codes with identifications engraved in the metal, consisting of the last name of the bat researcher plus a number. In Curitiba, bats were marked using bands signed PULCH LEITE plus a number, and in PETAR with bands signed ARNONE plus a number. Sex and reproductive condition was noted and the bats were then released at the same place of capture.

\section{Results}

On March 26, 2006, Arnone (2008) captured a marked $A$. lituratus female at Alambari de Baixo cave wearing a band used in a study other than his own. Two species of large Artibeus were previously recorded in the Alto Ribeira karst area (Trajano 1996), which are difficult to distinguish in the field. Moreover, the band was partially damaged, hampering a conclusive identification of its provenance. Therefore, the specimen was kept in order to confirm the species identification and to trace the origin of the band code. Afterwards, the code of the bat band was identified as PULCH LEITE 212, the last name of a bat researcher who was conducting a study in Curitiba. This individual was marked 14 months earlier on January 9, 2005. At first capture, the female was lactating; during recapture there was no sign of reproductive activity. 


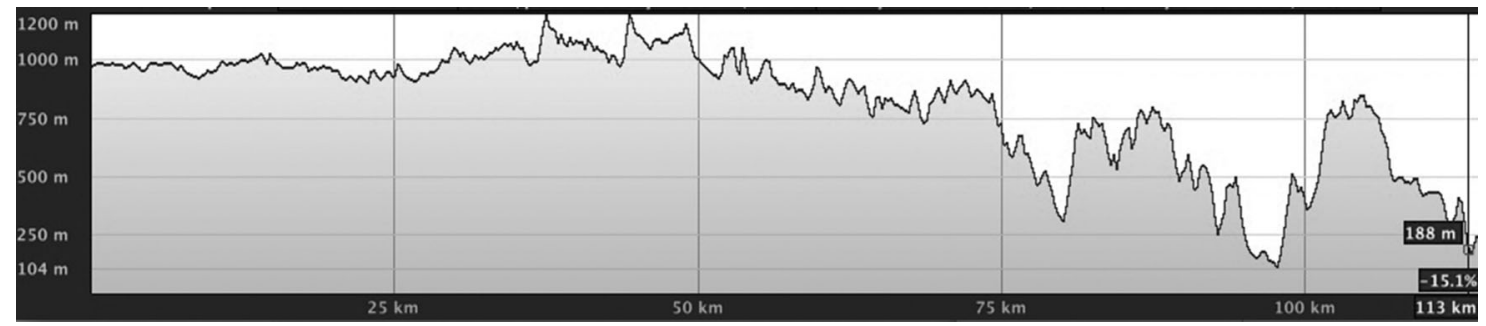

Figure 1. Elevation profile from point of capture to point of recapture of the female Artibeus lituratus.

The specimen was then euthanized and deposited as a voucher specimen in the collection of the Museu de Zoologia, Universidade de São Paulo (MZ33972).

The distance in straight line between the two localities, obtained with a line drawn by the ruler tool in the program Google Earth from point of capture to point of recapture, is ca. $113 \mathrm{~km}$, with a difference in altitude of $738 \mathrm{~m}$ (Figure 1).

\section{Discussion}

The longest bat movement previously recorded in Brazil was also of a female $A$. lituratus, which was first captured in a locality in the state of Pará (northern Brazil) and then recaptured 210 days later, $60 \mathrm{~km}$ away (Bernard \& Saldanha 2004). Movements covering dozens of kilometers between forest remnants, parks and urban areas, all of large Artibeus spp., have been reported in eastern Brazil. Esbérard (2003) recorded a movement of $21 \mathrm{~km}$ for a specimen of A. lituratus, and $25 \mathrm{~km}$ for a specimen of $A$. fimbriatus Gray, 1838 (author does not inform the sexes), both in Rio de Janeiro. In the same state, Costa et al. (2006) recorded a movement of $21.7 \mathrm{~km}$ after 20 days of a male $A$. fimbriatus between Ilha Grande, an island, and Mangaratiba, the mainland, with a minimum distance of $5 \mathrm{~km}$ over sea. Menezes- Jr et al. (2008) recorded a $34.8 \mathrm{~km}$ long movement for an A. lituratus female, with 97 days between captures between Parque Natural Municipal Serra da Medanha and Itacuruçá Island, implying flight with a minimum distance of $500 \mathrm{~m}$ over sea. In Espírito Santo state, Mendes et al. (2009) recorded a movement of $35.9 \mathrm{~km}$ for a male of $A$. lituratus.

Morrison (1979), using radiotelemetry, described that individuals of Artibeus jamaicensis Leach 1821 usually forage within a radius of 10 to $15 \mathrm{~km}$ away from their day roost. The distance between feeding roosts and fruiting trees utilized by radio-tagged $A$. jamaicensis ranged from 25 to $400 \mathrm{~m}$, and the number of feeding sites visited was influenced by moon phase; day roosts tended to be further away and might have been frequently changed, possibly in order to decrease the risks of predation (Morrison 1980). In a more recent study, Albrecht et al. (2007) showed that the home range size for Artibeus watsonii Thomas 1901 was highly variable among the five animals tracked, ranging from 1.8 to 17.9 ha with a mean of about 9 ha.

Larger mammals establish extensive home ranges (MacNab 1963, Lindstedt et al. 1986, Swihart et al. 1988). The same would be expected for large bat species. According to Fleming (1982), because large bats are able to fly faster, their foraging areas should be more extensive than those of small bats. However, the broad wings with low aspect ratio of Stenodermatinae bats are not wellsuited for long-distance migrations (Noberg and Rayner 1987). Hence, the movement presently recorded of $100 \mathrm{~km}$ by a female of A. lituratus may be considered as long-distance movement, and is therefore biologically significant data for stenodermatins.
As aforementioned, several authors raised the hypothesis of inter-regional migrations among Neotropical bats based on seasonal variation in the abundance of different species. Trajano $(1985,1996)$ observed a decline in the total abundance of cave bats in the Alto Ribeira karst area during the cooler, less rainy months (May to September). This was more evident for some common species, such as the frugivorous Carollia perspicillata (Linnaeus, 1758) and Artibeus fimbriatus Gray, 1838, and the nectarivorous/polinivorous Anoura caudifer (E. Geoffroy, 1818). The author suggests that during winter when nighttime temperature outside of caves may drop considerably (to a few degrees above $0^{\circ} \mathrm{C}$ in June to August), many bats would migrate to lower, warmer regions, possibly near the coast. This is consistent with data by Passos et al. (2003) for Parque Estadual Intervales (PEI), contiguous to PETAR, but occurring in higher altitudes (860 $\mathrm{m}$ a.s.1.) in which no Artibeus spp. was captured in the cooler months. During this time, fruits eaten by those bats (Cecropiacea) would be scarce. The same tendency of accentuated population decrease during the winter in PEI was observed by Mello et al. (2009) for S. lilium, also fruit-eating bats that are usually abundant throughout the year in lowlands (Giannini 1999, Aguiar and Marinho-Filho 2004).

Furthermore, Fazzolari-Corrêa (1995), studying the bat community in Parque Estadual da Ilha do Cardoso (PEIC), an estuary island situated on the coast of southern São Paulo state (minimum distance to the continent in a straight line being ca. $200 \mathrm{~m}$ ), observed that the three Artibeus spp., the large A. fimbriatus and A. lituratus, and the medium-sized $A$. obscurus (Schinz, 1821), among others, were captured more frequently during the warmer rainy season (November to April); whereas some other fruit-eating bats, such as $C$. perspicillata and Platyrrhinus lineatus (E. Geoffroy, 1810), were more abundant in cooler months. In a continental area near the Cardoso region, Geraldes (1999) obtained similar results for the three Artibeus spp., whereas Anoura geoffroyi Gray, 1838 bats were more frequently captured in the cooler months. On the other hand, Rosa (2004) found an increase in the capture frequency of A. lituratus bats at the beginning of the cooler season (April and May 2003) in Parque Estadual Rio da Onça, Matinhos, on the coast of Paraná at $3 \mathrm{~m}$ a.s.l. In the coolest season (June, July and August), average temperature was around $16-17^{\circ} \mathrm{C}$. This author suggested that the increase was caused by migration of some individuals to the region, because in this season temperature was warmer in lower altitudes and more food would be available when compared to highlands.

Some years ago, Esberard et al. (2011) gathered data on extensive year-round sampling at multiple elevations to test for evidence of altitudinal migration in Ipanema broad-nosed bats, Pygoderma bilabiatum (Wagner, 1843). P. bilabiatum was absent in regions where the temperature varied seasonally, 
and less common during cooler seasons at higher elevations. The authors concluded that these bats migrate altitudinally in response to seasonal variations, a conclusion supported by the constant abundance in regions where climate did not vary substantially.

In Costa Rica, long-term capture records at a montane site generated by Timm \& Laval (2000), revealed that several species were either completely absent during part of the year or showed substantial seasonal changes in abundance: A. lituratus, Artibeus toltecus (Saussure, 1860), Carollia brevicauda (Schinz, 1821), S. lilium and Hylonycteris underwoodi Thomas, 1903. These authors suggested that seasonal changes in abundance might represent altitudinal migration. Similarly, altitudinal migrations have been proposed to explain variations in seasonal abundances of $S$. lilium and Sturnira erythromos (Tschudi, 1844) in the Argentinian Andes (Giannini 1999).

Not unexpectedly, migratory movements were suggested for the free-tailed bat Tadarida brasiliensis (I.Geoffroy SaintHilaire 1824) in the city of Porto Alegre, southern Brazil, based on the decrease in number of individuals found in the colonies during winter (Marques 2003). North American populations of this nominal species are known to migrate seasonally between the USA and Mexico (Marques op. cit.), and similar ecological patterns are expected in South American areas with subtropical to temperate climate.

Direct and indirect evidence of bat migrations are also available for fully tropical regions of Brazil. For instance, in Reserva do Panga, Uberlândia area, Minas Gerais state, eastern Brazil, bats of most species were more frequently captured during the rainy season, including the fruit-eating $P$. lineatus, the nectarivorous Glossophaga soricina (Pallas, 1766), and Anoura caudifer (Pedro \& Taddei 2002). According to these authors, migrations of at least part of the $P$. lineatus population in the area would be associated with seasonal variations in fruit availability, as is the case of Cecropia sp. Long-distance bat movements in Amazonia, as recorded by Bernard \& Saldanha (2004) (discussed above), are probably also related to seasonal and/or inter-annual fluctuations in food resources.

It is noteworthy that, although able to sustain flight over distances of at least $5 \mathrm{~km}$, on the scale of their daily activities large Artibeus spp. are not particularly mobile, especially when compared to other plant-eating bats. Based on recapture rates and stability of colonies inside caves, Trajano (1996) concluded that in the Alto Ribeira karst area, A. fimbriatus bats are more sedentary than the smaller $C$. perspicilllata and $A$. caudifer bats. Likewise, in Pará state, Amazonia, the percentage of recaptures and mean distance between recaptures recorded by Bernard \& Fenton (2003) were similar for $C$. perspicillata and the large $A$. jamaicensis bats. Therefore, long distance movements by large Artibeus spp., just as those presently recorded, would be carried out in several steps, along some still unknown route(s). In fact, in all reported cases the time interval between recaptures was quite long, lasting several weeks.

We did not demonstrate cyclical two-way migratory movement sensu Krauel \& McCracken (2013) because the marked individual was collected as a voucher. However, the fact that it was a fully grown, reproductively active female (dispersal is more common among young individuals), associated with strong evidence of seasonal, thus migratory, movements in Artibeus spp., makes it reasonable to hypothesize that the $113 \mathrm{~km}$-long movement hereby recorded is part of an altitudinal migratory movement. Altitudinal migrations to lower areas would be the best solution to the problem of fruit shortage considering the following: 1) the significant altitudinal gradients over relatively short distances in Serra do Mar; 2) the high energetic demands throughout the year of non-hibernating bats; and 3) the generally positive correlation between temperature and fruit availability (as observed in the study areas), at least in the south-southeastern Brazilian countryside where winter may be very cold. The alternative, predominantly latitudinal migration, implies flying much longer distances, thus expending more energy.

Frugivorous bats, such as $C$. perspicillata and large and small-sized Artibeus species, may cross matrix areas in fragmented landscapes, flying over relatively long distances (up to $13 \mathrm{~km}$ - Bianconi 2009), connecting these elements and promoting forest regeneration by seed dispersion. However, these bats seem to be dependent on forest-structured areas (natural or restored) for day roosting (Trevelin et al. 2013, Ripperger et al. 2015). Riparian forests may be important routes for crossing degraded areas (Medina et al. 2007).

Implications for conservation are clear. The home range of these species, i.e., area required by individuals to complete their life cycle, must include forest-structured habitats and may be quite large, trespassing political borders and encompassing more than one biome. Investigating regional, latitudinal and altitudinal movements is necessary in order to understand temporal variations in the abundance of populations. Bat home ranges may be much larger than study areas viable for academic work, especially in the present academic climate ruled by the "publish or perish" philosophy, which imposes urgency, superficiality and fragmented science. In such a scenario, inter-team cooperation allowing data integration is of paramount importance for conservation, adding relevance to initiatives such as the one suggested by Trajano (2003), of a national program in Brazil using standardized permanent marks identifying the institution and/or researcher, with a centralized reference data system.

\section{Acknowledgements}

The authors are grateful to the administration of the Parque Estadual Turístico do Alto Ribeira (PETAR) for authorizing the collection of bats and use of the Park facilities. Park employees Sebastião Lopes, Cláudio Gomes and Gilberto Dalla Libera, helped us during fieldwork. Mary Andriani, native speaker, revised the English of the manuscript. This study was supported by the Conselho Nacional de Pesquisas CNPq (IA M. Sc. scholarship n. 134385/2005-5; ET fellowship n. 302956/2010-7, FCP fellowship n. 303757/2012-4). NOG IDEAWILD supplied equipment, such as mist nets, headlamps, calipers and dynamometers, which were used during the study.

\section{References}

AGUIAR, L.M.S. \& MARINHO-FILHO, J.S. 2004. Activity patterns of nine phyllostomid bat species in a fragment of the Atlantic Forest in southeastern Brazil. Revista Brasileira de Zoologia 21(2):385-390.

ALBRECHT, L., MEYER, C.F.J. \& KALKO, E.K.V. 2007. Differential mobility in two smallphyllostomid bats, Artibeus watsoni and Micronycteris microtis, in a fragmented Neotropical landscape. Acta Theriologica 52(2):141-149, http://dx.doi.org/10.1007/BF03194209.

ALERSTAM, T. \& A HERDENSTRÖM. 1998. The development of bird migration theory. Journal of Avian Biology 29: 343-369, http://dx.doi.org/10.2307/3677155. 
ARNONE, I.S. 2008. Estudo da comunidade de morcegos na área cárstica do Alto Ribeira - SP. Uma comparação com Trajano 1980. Dissertação de mestrado, Universidade de São Paulo, São Paulo.

AVILA-CABADILLA, L.D., STONER, K.E., HENRY, M. \& AÑORVE, M.Y.A. 2009. Composition, structure and diversity of Phyllostomid bat assemblages in different successional stages of a tropical dry forest. Forest Ecology and Management 258(6):986-996, http://dx.doi.org/10.1016/j.foreco.2008.12.011.

BERNARD E. \& FENTON M.B. 2003. Bat mobility and roost in a fragmented landscape in central amazonia, Brazil. Biotropica 35(2):262-277.

BERNARD, E. \& SALDANHA, L.N. 2004. Anilhamento de morcegos: um registro de deslocamento no Pará. XXV Congresso Brasileiro de Zoologia - Resumos, Brasília, p.235.

BIANCONI, G.V., MIKICH, S.B. \& PEDRO, W.A. 2006. Movements of bats (Mammalia, Chiroptera) in Atlantic Forest remmants is southern Brazil. Revista Brasileira de Zoologia 23(4):1199-1206, http://dx.doi.org/10.1590/S0101-81752006000400030.

BIANCONI, G.V. 2009. Morcegos frugívoros no uso do habitat fragmentado e seu potencial para a recuperação de áreas degradadas: subsídios para uma nova ferramenta voltada à conservação. Tese de Doutorado. Universidade Estadual Paulista, Rio Claro.

CHAPMAN, B.B., BRÖNMARK, C., NILSSON, J.é. \& HANSSON, L.A. 2011 The ecology and evolution of partial migration. Oikos 120:1764-1775, http://dx.doi.org/10.1111/j.1600-0706.2011.20131.x.

CHARLES-DOMINIQUE, P. 1991. Feeding strategy and activity budget of the frugivorous bat Carollia perspicillata (Chiroptera: Phyllostomidae) in French Guiana. Journal of Tropical Ecology 7: 243-256, http://dx.doi.org/10.1017/S026646740000540X.

COSTA, L.M., PRATA, A.F.D., MORAES, D., CONDE, C.F.V., JORDÃO-NOGUEIRA, T. \& ESBERARD, C.E.L. 2006. Deslocamento de Artibeus fimbriatus sobre o mar. Chiroptera Neotropical 12(2):289-290.

ESBERARD, C.E.L., DE LIMA, I.P., NOBRE, P.H., ALTHOFF, S.L., JORDÃO-NOGUEIRA, T., DIAS, D., CARVALHO, F., FABIÁN, M.E., SEKIAMA, M.L. \& SOBRINHO, A.S. 2011. Evidence of vertical migration in the lpanema bat Pygoderma bilabiatum (Chiroptera: Phyllostomidae: Stenodermatinae). Zoologia 28: 717-724, http://dx.doi.org/10.1590/S1984-46702011000600004.

ESBERARD, C.E.L. 2003. Marcação e deslocamentos em morcegos. Divulgações do Museu de Ciências e Tecnologia UBEA/PUCRS, publicação especial 2, Porto Alegre. p. 23-24.

FAZZOLARI-CORRÊA, S. 1995. Aspectos sistemáticos, ecológicos e reprodutivos de morcegos na Mata Atlântica. Tese de Doutorado. Universidade de São Paulo, São Paulo.

FENTON, M.B., ACHARYA, L., AUDET, D., HICKEY, M.B.C., MERRIMAN, C., OBRIST, M.K., SYME, D.M. \& ADKINS, B. 1992. Phyllostomid bats (Chiroptera:Phyllostomidae) as indicators of habitat disruption in the Neotropics. Biotropica 24: 440-446, http://dx.doi.org/10.2307/2388615.

FLEMING, T.H. \& EBY, P. 2003. Ecology of bat migration. In: Bat ecology (T.H. Kunz \& M.B. Fenton eds). University of Chicago Press, Chicago, p 156-208.

FLEMING, T.H. 1982. Foraging strategies of plant-visiting bats. In: Ecology of bats (T.H. Kunz, ed.). Plenum Press, New York, p.287-326, http://dx.doi.org/10.1007/978-1-4613-3421-7.

GANNON, M.R. \& WILLIG, M.R. 1997. The effect of lunar illumination on movement and activity of the red fig-eating bat (Stenodermarufum). Biotropica 29: 525-529, http://dx.doi.org/10.1111/ j.1744-7429.1997.tb00048.x.

GERALDES, M.P. 1999. Aspectos ecológicos da estruturação de um conjunto taxonômico de morcegos na região do Ariri, Cananéia, SP. Dissertação de Mestrado. Universidade de São Paulo, São Paulo.

GIANNINI, N. 1999. Selection of diet and elevation by sympatric species of Sturnira in an Andean rainforest. Journal of Mammalogy 80(4):1186-1195, http://dx.doi.org/10.2307/1383169.

GRIFFIN, D.R. 1945. Travels of banded cave bats. Jounal of Mammalogy 26: 15-23, http://dx.doi.org/10.2307/1375028.
GRIFFIN, D.R. 1970. Migrations and homing of bats. In: Bat biology and conservation (W.A. Wimsatt ed). Academic, New York, vol 1, p. $233-264$

KALKO, E.K.V. 1998. Organization and diversity of tropical bat communities through space and time. Zoology 101: 281-297.

KALKO, E.K.V., HERRE, E.A. \& HANDLEY, C.O. JR. 1996. Relation of fig fruit characteristics to fruit-eating bats in the new and old world tropics. Journal of Biogeography 23(4):565-576, http://dx.doi.org/10.1111/j.1365-2699.1996.tb00018.x.

KRAUEL, J.J. \& McCRACKEN, G.F. 2013. Recent advances in bat migration research. In: Bat evolution, Ecology and Conservation (R.A. Adams \& S.C. Pedersen eds). Springer Science, New York, p. 293-314, http://dx.doi.org/10.1007/978-1-4614-7397-8.

LEITE, A.P. 2008. Uso do espaço por Artibeus lituratus e Sturnira lilium (Chiroptera: Phyllostomidae) em fragmentos florestais urbanos de Curitiba, Paraná. Tese de doutorado. Universidade Federal do Paraná, Curitiba.

LINDSTEDT, S.L., MILLER, B.J. \& BUSKIRK, S.W. 1986. Home range, time, and body size in mammals. Ecology 67(2):413-418, http://dx.doi.org/10.2307/1938584.

MACNAB, B.K. 1963. Bioenergetics and the determination of home range size. The American Naturalist 894(157):133-140, http://dx.doi.org/10.1086/282264.

MARQUES, R.V. 2003. Migração, deslocamento e anilhamento. Divulgações do Museu de Ciências e Tecnologia UBEA/PUCRS, publicação especial 2, Porto Alegre. p. 19-21.

McCRAKEN, G.F., McCRAKEN, M.K. \& VAWTER, A.T. 1994. Genetic structure in migratory populations of the bat Tadarida brasiliensis mexicana. Journal of Mammalogy 75: 500-514, http://dx.doi.org/10.2307/1382574.

MCGUIRE, L.P. \& BOYLE, W.A. 2013. Altitudinal migrations in bats: evidence, patterns, and drivers. Biological Reviews 88: 767-786, http://dx.doi.org/10.1111/brv.12024.

MEDINA, A., HARVEY, C.A., MERLO, D.S., VÍlCHEZ, S. \& HERNÁNDEZ, B. 2007. Bat diversity and movement in an agricultural landscape in Matiguás, Nicaragua. Biotropica 39:120-128, http://dx.doi.org/10.1111/j.1744-7429.2006.00240.x.

MELLO, M.A.R., KALKO, E.K.V. \& SILVA, W.R. 2009. Ambient temperature is more important than food availability in explaining reproductive timing of the bat Sturnira lilium (Mammalia: Chiroptera) in a montane Atlantic Forest. Canadian Journal of Zoology- Revue Canadienne de Zoologie 87(3):239-245, http://dx.doi.org/10.1139/Z09010.

MELLO, M.A.R., KALKO, E.K.V. \& SILVA, W.R. 2008. Movements of the bat Sturnira lilium and it's role as a seed disperser of Solanaceae in the Brazilian Atlantic forest. Journal of Tropical Ecology 24: 225-228, http://dx.doi.org/10.1017/S026646740800480X.

MENDES, P., VIEIRA, T.B., OPREA, M. \& DITCHFIELD, A.D. 2009. Long-distance movement of Artibeus lituratus (Chiroptera: Phyllostomidae) in the State of Espirito Santo, Brazil. Ecotropica 15: 43-46.

MENEZES-JR, L.F., DUARTE, A.C. \& NOVAES, R.L.M. 2008. Deslocamento de Artibeus lituratus (Olfers, 1818) (Mammalia, Chiroptera) entre ilha e continente no Estado do Rio de Janeiro, Brasil./ www.biotaneotropica.org.br/v8n2/en/abstract?short-communication + bn00808022008.

MORRISON, D.W. 1979. Apparent male defense of tree hollows in the fruit bat Artibeus jamaicensis. Journal of Mammalogy 60: 11-15, http://dx.doi.org/10.2307/1379753.

MORRISON, D.W. 1980. Foraging and day-roosting dynamics of canopy fruit bats in Panama. Journal of Mammalogy 61(1):20-29, http://dx.doi.org/10.2307/1379953.

MUSCARELLA, R. \& FLEMING, T.H. 2007. The Role of Frugivorous Bats in Tropical Forest Succession. Biological Reviews of the Cambridge Philosophical Society 82 (4):573-590, http://dx.doi.org/10.1111/j.1469-185X.2007.00026.x.

NORBERG, U.M. \& RAYNER, J.M.V. 1987. Ecological morphology and flight in bats (Mammalia, Chiroptera): wing adaptations, flight 
performance, foraging strategy and echolocation. Philosophical transactions of the Royal Society of London, Series B, Biological Sciences, 1179(316):335-427, http://dx.doi.org/10.1098/rstb.1987. 0030.

PASSOS, F.C., SILVA, W.R., PEDRO, W.A. \& BONIN, M.R. 2003. Frugivoria em morcegos (Mammalia, Chiroptera) no Parque Estadual Intervales, sudeste do Brasil. Revista Brasileira de Zoologia 20 (3):511-517, http://dx.doi.org/10.1590/S0101-81752003000300024.

PEDRO, W.A. \& V.A. TADDEI 2002. Temporal distribution of five bat species (Chiroptera, Phyllostomidae) from Panga Reserve, South-eastern Brazil. Revista Brasileira de Zoologia 19(3):951-954, http://dx.doi.org/10.1590/S0101-81752002000300033.

RIPPERGER, S.P., KALKO, E.K.V., RODRÍGUEZ-HERRERA, B., MAYER, F., TSCHAPKA, M. 2015. Frugivorous bats maintain functional habitat connectivity in agricultural landscapes but rely strongly on natural forest fragments. PLoS ONE 10:e0120535, doi: http://dx.doi.org/10.1371/journal.pone.0120535.

ROSA, S.D. 2004. Morcegos (Chiroptera, Mammalia) de um remanescente de restinga, Paraná, Brasil: Ecologia da comunidade e dispersão de sementes. Dissertação de mestrado. Universidade Federal do Paraná, Curitiba.

SWIHART, R.K., SLADE, N.A. \& BERGSTROM, B. 1988. Relating body size to the rate of home range use in mammals. Ecology 69(2): 393-399, http://dx.doi.org/10.2307/1940437.
TIMM, R.M. \& LAVAL, R.K. 2000. Mammals. In: Monteverde: Ecology and Conservation of a Tropical Cloud Forest (N.M. Nadkarni \& N.T. Wheelwright eds). Oxford University Press, New York, p. 223-244.

TRAJANO, E. 1985. Ecologia de populações de morcegos cavernícolas em uma região cárstica do sudeste do Brasil. Revista Brasileira de Zoologia 2(5):255-320, http://dx.doi.org/10.1590/S0101-81751984000100001.

TRAJANO, E. 1996. Movements of cave bats in southeastern Brazil, with emphasis on population ecology of commom vampire bat, Desmodus rotundus (Chiroptera). Biotropica 28(1):121-129, http://dx.doi.org/10.2307/2388777.

TRAJANO, E. 2003. Morcegos tropicais migram? Proposta de programa nacional de marcação em Chiroptera. Divulgações do Museu de Ciências e Tecnologia UBEA/PUCRS, publicação especial 2, Porto Alegre, p. 21-23.

TREVELIN, L.C., SILVEIRA, M., PORT-CARVALHO, M., HOMEM, D.H. \& CRUZ-NETO, A.P. 2013. Use of space by frugivorous bats (Chiroptera: Phyllostomidae) in a restored Atlantic Forest fragment in Brazil. Forest Ecology and Management 291: 136-143, http://dx.doi.org/10.1016/j.foreco.2012.11.013.

TUTTLE, M.D. 1976. Population ecology of the gray bat (Myotis grisescens): philopatry timing and patterns of movement weight loss during migration and seasonal adaptive strategies. Occasional Papers of the Museum of Natural History University of Kansas 54: 1-38.

Received 12/03/2015

Revised 4/11/2015

Accepted 18/11/2015 